\title{
Rat brain polyamines: an analytical method validation
}

\author{
Poliaminas no cérebro do rato: validação de método analítico
}

Valdomiro de Freitas Sampaio'; Gilberto J. Padovan²; Julio Sérgio Marchini; Luiz Marcellino de Oliveira4; Sebastião Sousa Almeidas;

resumo

A validação técnica analítica para determinação de poliaminas em tecido cerebral utilizando cromotografia líquida de alta eficiência (HPLC) e derivação pós-coluna com o-ftaldialdeído é descrita. A separação das poliaminas deu-se em coluna LiChrospher 100 RP18. O gradiente de eluição foi formado por duas fases móveis $A$ (acetato de sódio 0,1M + octanossulfonato de sódio 0,01 M) e B (acetato de sódio 0,2 M + octanossulfonato de sódio 0,01 M)/acetonitrila (10:3), fluxo de 1,2 ml/min. O eluente foi monitorado por fluorescência (excitação, $345 \mathrm{~nm}$; emissão, $455 \mathrm{~nm}$ ). Além da excelente linearidade (putrescina, $r=0,9816$; espermidina, $r=0,9920$; espermina, $r=0,9901$ ), a técnica demonstrou adequada precisão intra e interdia $(\leq 20 \%)$ e recuperação (espermidina $=92,56 \%$; espermina $=84,47 \%$ ). Os limites de quantificação foram 0,22 pM para putrescina, 76,44 pM para espermidina e 51,44 pM para espermina. O método demonstrou ser consistente, simples e altamente reprodutível para a determinação proposta.

\footnotetext{
\begin{tabular}{l|l}
\multicolumn{1}{c|}{ key words } & abstract \\
Validation & The validation of the analytical technique for the determination of polyamines in cerebral tissue using \\
Analytical technique & HPLC based on o-phthalaldehyde post-column derivatization is described. The polyamines were \\
separated in a LiChrospher100 RP18 column. Elution gradient was formed with two mobile phases: & A (sodium acetate $0.1 \mathrm{M}+$ sodium octanesulphonate $0.01 \mathrm{M}, \mathrm{pH}=4.5)$ and B (sodium acetate \\
Polyamines & $\begin{array}{l}0.2 \mathrm{M}+\text { sodium octanesulphonate } 0.01 \mathrm{M}) / \text { acetonitrile }(10: 3), \mathrm{pH}=4.5) \text { in a } 1.2 \mathrm{ml} / \mathrm{min} \text { flow rate. } \\
\text { The derivative eluent was monitored by fluorescence (excitation, } 345 \mathrm{~nm} \text {; emission, } 455 \mathrm{~nm} \text { ). Besides } \\
\text { excellent linearity (putrescine, } r=0.9816 ; \text { spermidine, } r=0.9920 ; \text { spermine, } r=0.9901) \text {, the technique } \\
\text { demonstrated intra and inter-day precision }(\leq 20 \%) \text { as well as recovery (spermidine }=92.56 \% ; \\
\text { spermine }=84.47 \%) \text {. Quantification limits were } 0.22 \mathrm{pM} \text { for putrescine, } 76.44 \mathrm{pM} \text { for spermidine } \\
\text { and } 51.44 \text { pM for spermine. The method demonstrated to be robust, simple and highly reproducible } \\
\text { for polyamine determination in tissues. }\end{array}$
\end{tabular}

key words
}

unitermos

Validação

Técnica analítica

HPLC

Poliaminas

\footnotetext{
1. Doutor em Ciências pela Faculdade de Filosofia, Ciências e Letras de Ribeirão Preto da Universidade de São Paulo (USP); médico ginecologista/obstetra.

2. Químico do Laboratório de Espectrometria de Massa da Divisão de Nutrição do Departamento de Clínica Médica da Faculdade de Medicina de Ribeirão Preto (FMRP) da USP.

3. Professor titular da USP; bolsista de Produtividade em Pesquisa 1A; orientador de mestrado e doutorado.

4. Professor assistente MS-3 da Faculdade de Filosofia, Ciências e Letras de Ribeirão Preto da USP, in memorian.

5. Professor titular da Faculdade de Filosofia, Ciências e Letras de Ribeirão Preto da USP.
} 


\section{Introduction}

The polyamines are low molecular weight aliphatic cations occurring in all living organisms ${ }^{(15)}$. The biogenic polyamines evaluated in this study are putrescine $\left(\mathrm{H}_{2} \mathrm{~N}\left(\mathrm{CH}_{2}\right)_{4} \mathrm{NH}_{2}\right)$, spermidine $\left(\mathrm{H}_{2} \mathrm{~N}\left(\mathrm{CH}_{2}\right)_{3} \mathrm{NH}\left(\mathrm{CH}_{2}\right)_{4} \mathrm{NH}_{2}\right)$ and spermine $\left(\mathrm{H}_{2} \mathrm{~N}\left(\mathrm{CH}_{2}\right)_{3} \mathrm{NH}\left(\mathrm{CH}_{2}\right)_{4} \mathrm{NH}\left(\mathrm{CH}_{2}\right)_{3} \mathrm{NH}_{2}\right)$. Putrescine is synthesized in mammals from L-ornithine in a catalyzed reaction by ornithine decarboxylase, an enzyme limiting from the polyamine synthesis. Putrescine and $S$-adenosylmethionine are substrates for the spermidine synthesis, which is the precursor of spermine.

Among the various physiologic functions of the polyamines, we can categorize its performance as a second messenger, nutrient, metabolic regulator, growth factor, anti-oxidant, DNA, RNA and membrane stabilizer ${ }^{(17)}$.

The cells developed mechanisms in order to assure the rigorous regulation of the intracellular polyamine levels through biosynthesis processes, degradation and transportation inside the organism ${ }^{(12)}$. Insufficient polyamines levels result in a deficit growth and, in some cases, cellular death, including apoptosis. The uncontrolled elevation of the polyamines can lead to cellular transformation and tumor genesis ${ }^{(11)}$.

The objective of the present study was to validate a modified version of the polyamine determination as described by Löser et al.(10) using reverse phase ion-pair high performance liquid chromatography (HPLC), followed by o-phtalaldehyde post column derivatization and fluorescence detection.

\section{Methods}

\section{Animals}

In these experiments, male Wistar (Rattus norvegicus) rats from the animal colony of Ribeirão Preto Campus, University of São Paulo were used. The animals were maintained on a 12:12-h light/dark cycle (lights on at 6:00 am) with room temperature kept at $23-25^{\circ} \mathrm{C}$, and with free access to water and food. The experiments were performed in compliance with the recommendations of the Brazilian Society of Neuroscience and Behavior ( $\mathrm{SBNeC}$ ), which is based on the US National Institutes of Health Guide for Care and Use of Laboratory Animals.

\section{Apparatus and chromatographic conditions}

In the quantitative determination of polyamines in cerebral tissue, a chromatograph from Shimadzu
Corporation - model LC-10AD was used, equipped with two Shimadzu LC-10AD high pressure pumps, a Shimadzu CBM-10A gradient mixture unit, a Shimadzu SIL-10A autosampler and a Shimadzu CTO-10A oven to keep the column at $37 \pm 1{ }^{\circ} \mathrm{C}$. A LiChrospher ${ }^{\circledR} 100 \mathrm{RP} 18$ column was used for the polyamine separation, containing octadecilsilane (C18), with $120 \times 4.0 \mathrm{~mm}$ i.d. and $5 \mu \mathrm{m}$ particle diameter. The column gradient flow was kept at $1.2 \mathrm{ml} / \mathrm{min}$. A low pressure pump from Milton Roy Company with a $0.45 \mathrm{ml} / \mathrm{min}$ flow was used to accomplish the o-phtalaldehyde (OPA) post-column derivatization. The column eluent and OPA derivatizing agent were mixed in a $\mathrm{T}$ connection and, after passing through a polypropylene coil $(1 \mathrm{~m} \times 0.5 \mathrm{~mm}$ i.d.), as described by Seiler et al. ${ }^{(13)}$, were maintained in a water bath at $54 \pm 1^{\circ} \mathrm{C}$, controlled by a thermostat. After reaction, the eluent-reagent mixture went through a Shimadzu RF535 fluorescence detector, with excitation and emission wavelengths of $345 \mathrm{~nm}$ and $455 \mathrm{~nm}$, respectively.

\section{Reagents}

The following polyamine standards were acquired: putrescine (1.4-diaminobutane) 99\% Sigma D13208 with a molecular weight of $88.15 \mathrm{MW}$, spermidine (free base spermidine Sigma S2626 with a $145.25 \mathrm{MW}$ ), spermine (free base spermine Sigma S3256 with a 202.34 $\mathrm{MW})$ and the internal standard (1,7-diaminoheptane Sigma 32990 with a $130.23 \mathrm{MW}$ ). The octanesulfonic sodium (1-octanesulfonic sodium acid Vetec Brasil with a 234.29 MW), the ophthalaldehyde (ophthaldialdeyde Acros with a $134.13 \mathrm{MW}$ ) and the Brij35 detergent (Acros with a $1198 \mathrm{MW}$ ) were categorized as a pure level to HPCL. The percloric acid at 70\% (Cinética Química, Brazil), the acetonitrile (J. T. Baker), the PA sodium acetate (Merck), the potassium hydroxide, ethanol, 2-mercaptoethanol, PA acetic acid (Vetec Brasil) and the PA boric acid (Vetec Brasil) were analytical. MILLEX-GS filters with $13 \mathrm{~mm}$ diameter and $0.22 \mu \mathrm{m}$ pore from Millipore (JBR13GP05) were acquired. The water used was from the usage of the Milli-Q (Millipore) system. For the protein dosage, the Coomassie blue binding method ${ }^{(2)}$ was implemented, using the Dye Reagent Concentrate (BIO-RAD Protein Assay) and bovine albumin (PIERCE Protein assay reagents).

\section{Solutions}

- Buffer A: $0.1 \mathrm{M}$ sodium acetate and $0.01 \mathrm{M}$ sodium octanesulfonate solution: obtained by the addition of sodium acetate $(16.41 \mathrm{~g})$ and sodium 
octanesulfonate ( $4.69 \mathrm{~g}$ ) to 2,000 ml Milli-Q water, having the $\mathrm{pH}$ adjusted to 4.5 by the addition of acetic acid.

- Buffer B: $0.2 \mathrm{M}$ sodium acetate and $0.01 \mathrm{M}$ sodium octanesulfonate solution was obtained by the addition of sodium acetate $(32.81 \mathrm{~g})$ and sodium octanesulfonate $(4.69 \mathrm{~g}$ ) to 2,000 ml Milli-Q water, having the $\mathrm{pH}$ adjusted to 4.5 by the addition of acetic acid. To an aliquot of this solution we add acetonitrile in a 10:3 ( $\mathrm{v} / \mathrm{v})$ proportion in order to create Buffer B. Both buffers (A and B), were filtered, after agitation, through a cellulose (or nylon) organic phase filter with $0.45 \mu \mathrm{m}$ pore and $47 \mathrm{~mm}$ diameter.

- Boric acid solution: obtained after addition of boric acid $(12.34 \mathrm{~g})$ and potassium hydroxide at $25 \%$ ( $25 \mathrm{ml}$ ) to $1,000 \mathrm{ml}$ Milli-Q water, having the $\mathrm{pH}$ adjusted to 10.4 with addition of potassium hydroxide at $50 \%$

- OPA-methanol solution: obtained after adding OPA (400 mg) to methanol (5 ml).

- OPA-2-mercaptoetanol derivatizing reagent solution: obtained after adding the boric acid solution $(227.3 \mathrm{ml}), 30 \%$ BRIJ35 $(6.82 \mathrm{ml})$, 2-mercaptoethanol $(4.55 \mathrm{ml})$ and the OPAmethanol solution $(11.36 \mathrm{ml})$. The derivatizing reagent must be kept in a dark flask protected from light and pressurized under constant low helium flow.

- $0.2 \mathrm{M}$ percloric acid solution (PCA): obtained after addition of $70 \%$ PCA $(4.31 \mathrm{ml})(\mathrm{MW}=100.46$, density $=1.664 \mathrm{~g} / \mathrm{ml}$ ) to $250 \mathrm{ml}$ distilled water.

- Internal standard solution: obtained after adding 1.7 diaminoheptane $(0.039 \mathrm{mg})$ to buffer A $(10 \mathrm{ml})$, which gives a $300 \mathrm{nmol} / \mathrm{ml}$ concentration.

- Polyamines Standards Mixture (PSM) for the standards curves and calibration runs, being made of:

$\sqrt{ } 13,822 \mathrm{nM}$ internal standard 1.7 diaminoheptane solutions $(160 \mu \mathrm{l})$ : obtained after adding 1.7 diaminoheptane $(0.09 \mathrm{mg})$ to buffer $\mathrm{A}(50 \mathrm{ml})$.

$\sqrt{ } 846.3 \mathrm{nM} 1.4$ diaminobutane (putrescine) solution $(40 \mu \mathrm{l})$ : obtained after adding 1.4 diaminobutane $(0.000373 \mathrm{mg})$ to buffer $A$ $(5 \mathrm{ml})$.

$\sqrt{ } \quad 63.7 \mu \mathrm{M} \mathrm{N}$-(3-aminopropil)-1.4 diaminobutane (spermidine) solution $(30 \mu \mathrm{l})$ : obtained after adding spermidine $(0.23131 \mathrm{mg})$ to buffer $\mathrm{A}$ $(25 \mathrm{ml})$.

$\sqrt{ } 32,122 \mathrm{nM}$ N,N'-Bis(3-aminopropil)-1.4 diaminobutane (spermine) solution $(8 \mu \mathrm{l})$ : obtained after adding spermine $(0.03250 \mathrm{mg})$ to buffer A $(5 \mathrm{ml})$.

$\sqrt{ }$ Buffer $A(5,000 \mu l)$.

The final PSM content concentrations are: putrescine $(6.77 \mathrm{nM})$, internal standard (44.22 $\mathrm{nM})$, spermidine (76.44 $\mathrm{nM})$ and spermine $(51.40 \mathrm{nM})$.

\section{Elution gradient}

The elution gradient described in Table 1 was used in the HPLC analysis. The column flux was $1.2 \mathrm{ml} / \mathrm{min}$, with a 17 minutes elution run time, followed by a 8 minutes equilibration time, summing up to 25 minutes total analysis time.

\section{Table 1 Buffers elution gradients used}

\begin{tabular}{|c|c|c|c|c|c|}
\hline & & $\begin{array}{c}\text { Buffer } \\
\text { A }\end{array}$ & $\begin{array}{c}\text { Buffer } \\
\text { B }\end{array}$ & $\begin{array}{c}\text { Buffer } \\
\text { A }\end{array}$ & $\begin{array}{c}\text { Buffer } \\
\text { B }\end{array}$ \\
\hline & $\begin{array}{c}\text { Elution } \\
\text { time } \\
\text { (min.) }\end{array}$ & $\%$ & $\%$ & flow & flow \\
\hline & & & & $\mathrm{ml} / \mathrm{min}$ & $\mathrm{ml} / \mathrm{min}$ \\
\hline \multirow{7}{*}{$\begin{array}{l}\text { Equilibrium } \\
\text { time (min.) } \\
\text { Total time } \\
\text { (min.) }\end{array}$} & 0 & 50 & 50 & 0.6 & 0.6 \\
\hline & 10 & 25 & 75 & 0.3 & 0.9 \\
\hline & 12 & 0 & 100 & 0 & 1.2 \\
\hline & 16 & 0 & 100 & 0 & 1.2 \\
\hline & 17 & 50 & 50 & 0.6 & 0.6 \\
\hline & 8 & & & & \\
\hline & 25 & & & & \\
\hline
\end{tabular}

\section{Sample extraction procedure}

The extraction procedure was conducted according to Löser et al. ${ }^{(10)}$. After weighting, the samples were frozen to $-70^{\circ} \mathrm{C}$, being reported that under this condition, we can wait up to six months for further analysis( ${ }^{(6)}$.

In the analysis day, after defrost the sample at ambient temperature, a $0.9 \%$ saline solution was added to the eppendorf containing the sample in a 1:20 (weigth [g]/ volume $[\mathrm{ml}]$ ) proportion followed by a homogenization with a sonicator (Ultrasonic Processor Model GE 130PB) for 4 times of 5 seconds. After that, $250 \mu$ of the homogenate sample was removed and separated in another eppendorf, while the remaining sample was frozen to $-70^{\circ} \mathrm{C}$ for 
posterior protein quantification. The internal standard (1.7 diaminoheptane, $300 \mathrm{nM} / \mathrm{ml}$ ) solution $(50 \mu \mathrm{l})$ and $70 \%$ $0.2 \mathrm{M}$ PCA $(700 \mu \mathrm{l})$ were added to the homogenate. The mixture was then centrifuged at $3200 \mathrm{~g}$ for 5 minutes and the supernatant was filtered by a Millex $(0.22 \mu \mathrm{m})$ filter and $20 \mu \mathrm{L}$ were injected into the HPLC.

The PSM, routinely used in calibrations to obtain the analytical curve, which used to be done before the sample analysis, contained, in the $20 \mu \mathrm{l}$ injected into the HPLC, 27.08 picomoles of putrescine, 176.92 picomoles of the internal standard (1.7-diaminoheptane), 305.76 picomoles of spermidine and 205.6 picomoles of spermine.

\section{Technical analysis validation}

The technical analysis validation, confirming its applicability to the intentioned purpose, was accomplished based on the following parameters: linearity, detection and quantification limits, precision and recovery, following the $\mathrm{FDA}^{(1)}$ and $\mathrm{ICH}^{(8)}$ recommendations.

\section{Results and discussions}

\section{Chromatographic methodology}

In Figure, the chromatogram shows the retention times of putrescine (about 6 minutes), internal standard (11 minutes), spermidine (14 minutes) and spermine (16 minutes) during the sample analysis from the cerebral tissue of the rat.

\section{Linearity}

The linearity of the polyamines responses was examined to ensure that the procedure can provide quantitative

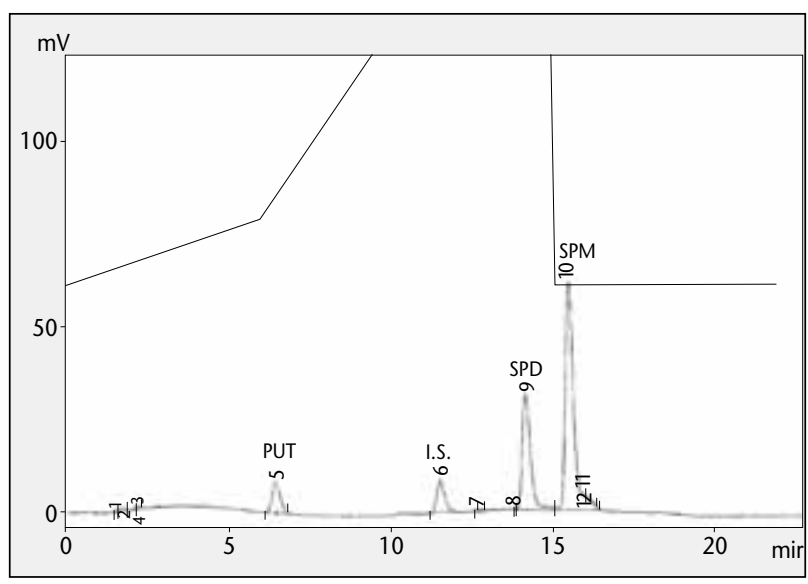

Figure - Chromatogram of the cerebral tissue of the rats showing the retention peaks for putrescine (5), internal standard (6), spermidine (9) and spermine (10). analysis. Therefore, analytical curves were built starting from the solution obtained from the addition of the PSM $(200 \mu \mathrm{l})$ to Buffer A ( $200 \mu \mathrm{l})$ with triplicate analysis of $10,20,30,40$ and $50 \mu \mathrm{l}$ injected solution. The linear regression analysis for the relation between the injected concentration and the detector response for putrescine (PUT), spermidine (SPD) and spermine (SPM) as well as correlation coefficients and linearity equations are shown below in Table $\mathbf{2}$.

\section{Precision}

The precision, defined as the agreement pattern between the results of individual tests when the procedure is applied to multiple aliquots of a homogenized sample, was accomplished through the evaluation of the repeatability, or intra-assay or intra-day, precision, and the intermediate, or inter-assay or inter-day, precision ${ }^{(14)}$. Three male Wistar rat brains were submitted to the same extraction procedure described above, each brain supplying a homogenized solution. Fifteen samples from each homogenized solution where analyzed in quintuplicate $(n=5)$ for intra-day assay and triplicate $(n=15)$ for inter-day assay.

In the precision and recovery studies there were no results regarding putrescine, which concentration in the used samples was below the detection limit. The intra and inter day coefficients obtained in the method precision are summarized in Tables $\mathbf{3}$ and $\mathbf{4}$ and are according to what was expected $(\leq 20 \%)^{(1)}$.

\section{Recovery}

For the polyamines recovery analysis, a whole rat brain was used. Fifteen samples of an homogein sample

Table 2 Linear regression analysis of the relation between concentration and peak area of putrescine (PUT), spermidine (SPD) and spermine (SPM)

\begin{tabular}{|c|c|c|c|c|}
\hline Substance & $\begin{array}{l}\text { Corr. coef. } \\
(r)\end{array}$ & $\begin{array}{l}\text { Slope } \\
(\text { a) } \pm S D\end{array}$ & Intercept-X & $\begin{array}{l}\text { Intercept-Y } \\
\text { (b) }\end{array}$ \\
\hline PUT & 0.981631 & $\begin{array}{r}16530 \\
\pm 858.8\end{array}$ & 1.233 & $\begin{array}{c}-20380 \pm \\
18670\end{array}$ \\
\hline SPD & 0.992018 & $\begin{array}{c}3093 \pm \\
105.2\end{array}$ & -5.579 & $\begin{array}{c}17260 \pm \\
25830\end{array}$ \\
\hline SPM & 0.990051 & $\begin{array}{c}2865 \pm \\
108.9\end{array}$ & 8.071 & $\begin{array}{r}-23 \\
17\end{array}$ \\
\hline
\end{tabular}


Intra-day precision in quintuplicate showing mean (picomoles), standard deviation (SD), standard Table 3 mean error (SME) and coefficient of variation (CV) of the measures

\begin{tabular}{|c|c|c|c|c|c|c|c|c|}
\hline \multicolumn{9}{|c|}{ Intra-day precision } \\
\hline \multicolumn{4}{|c|}{ SPD } & & \multicolumn{4}{|c|}{ SPM } \\
\hline Days & 1 & 2 & 3 & & Days & 1 & 2 & 3 \\
\hline Mean & 287.8 & 291.5 & 236.7 & \multirow{4}{*}{ ANIMAL 1} & Mean & 126.2 & 115.7 & 83.19 \\
\hline SD & 3.234 & 11.45 & 5.38 & & SD & 24.14 & 3.884 & 6.073 \\
\hline SME & 1.867 & 6.612 & 2.477 & & SME & 13.94 & 2.746 & 3.037 \\
\hline CV & $1.12 \%$ & $3.93 \%$ & $2.34 \%$ & & CV & $19.13 \%$ & $3.36 \%$ & $7.3 \%$ \\
\hline Days & 1 & 2 & 3 & & Days & 1 & 2 & 3 \\
\hline Mean & 229.2 & 268.2 & 254.6 & \multirow{4}{*}{ ANIMAL 2} & Mean & 84.21 & 117.8 & 104.1 \\
\hline SD & 5.739 & 22.53 & 15.02 & & SD & 4.759 & 10.41 & 11.54 \\
\hline SME & 2.869 & 10.08 & 6.718 & & SME & 2.128 & 4.655 & 5.161 \\
\hline CV & $2.5 \%$ & $8.4 \%$ & $5.9 \%$ & & CV & $5.65 \%$ & $8.84 \%$ & $11.08 \%$ \\
\hline Days & 1 & 2 & 3 & & Days & 1 & 2 & 3 \\
\hline Mean & 277.4 & 243.4 & 218.3 & \multirow{4}{*}{ ANIMAL 3} & Mean & 69.96 & 163.5 & 39.01 \\
\hline SD & 25.44 & 8.075 & 2.814 & & SD & 11.57 & 20.09 & 0.891 \\
\hline SME & 11.38 & 4.038 & 1.625 & & SME & 5.176 & 11.6 & 0.4455 \\
\hline $\mathrm{CV}$ & $9.17 \%$ & $3.32 \%$ & $1.29 \%$ & & $\mathrm{CV}$ & $16.54 \%$ & $12.29 \%$ & $2.28 \%$ \\
\hline
\end{tabular}

Precision calculation of 3 days $(n=15)$ showing the average (picomoles), the

Table 4 standard deviation (SD), the standard mean error (SME) and the coefficient of variation (CV) of the measures

\begin{tabular}{|c|c|c|c|}
\hline \multicolumn{4}{|c|}{ Intra-day precision } \\
\hline & & SPD & SPM \\
\hline \multirow{4}{*}{$\begin{array}{c}\text { ANIMAL } \\
1\end{array}$} & Mean & 267.4 & 101.7 \\
\hline & SD & 29.4 & 19.73 \\
\hline & SME & 8.16 & 6.24 \\
\hline & CV & $10.99 \%$ & $19.4 \%$ \\
\hline \multirow{4}{*}{$\begin{array}{c}\text { ANIMAL } \\
2\end{array}$} & Mean & 249.1 & 102 \\
\hline & SD & 24.52 & 16.71 \\
\hline & SME & 6.33 & 4.31 \\
\hline & CV & $9.84 \%$ & $16.37 \%$ \\
\hline \multirow{4}{*}{$\begin{array}{c}\text { ANIMAL } \\
3\end{array}$} & Mean & 252.60 & 73.44 \\
\hline & SD & 36.89 & 10.47 \\
\hline & SME & 9.53 & 3.7 \\
\hline & CV & $14.6 \%$ & $14.26 \%$ \\
\hline
\end{tabular}

obtained from the extraction procedure described above were analyzed in triplicate, with and without addition of known quantities of polyamine standards: $92.56 \%$ and
$84.47 \%$ were the recovery percentage for spermidine and spermine, respectively.

\section{Method modification for putrescine detection}

The largest HPLC injection volume, from $20 \mu \mathrm{L}$ to $30 \mu \mathrm{L}$, elevating from 1.5 times the solute mass, did not successfully result in detection of putrescine in the samples. After that, in an attempt to detect putrescine, we concentrated the samples in a way that the injected mass quintuplicated. Therefore, the original saline dilution proposed by Löser et al. ${ }^{(10)}$ was reduced from 1:20 to 1:10 and the PCA volume from the original proportion of 2.8:1 (homogenate volume /PCA volume) to 1.2:1. The additional internal standard volume remained in the same original $1 / 5$ proportion of the homogenate volume. Consequently, for a homogenate volume of $250 \mu \mathrm{l}$, for instance, we added $50 \mu \mathrm{l}$ of the internal standard, a procedure we maintained, and $300 \mu \mathrm{l}$ of PCA. Finally, to elevate 5 times the injected mass, we injected $30 \mu \mathrm{L}$ into the HPLC. These alterations in the method succeeded in the putrescine detection.

\section{Detection and quantification limits}

The detection limits for each polyamine were calculated considering a 2:1 signal/noise level. Following this criteria, 
the detection limits obtained resulted in 0.11 picomoles for putrescine, 27.56 picomoles for spermidine and 20.69 picomoles for spermine.

For the quantification limit, the lowest analit concentration that provides an answer which could be accurately quantified resulted in 0.22 picomoles for putrescine, 76.44 picomoles for spermidine and 51.40 picomoles for spermine, considering a 10:1 signal/noise relation.

\section{Conclusion}

The highly sensitive and reproducible chromatographic method developed by Löser et al. ${ }^{(10)}$, used in this study as well as in others ${ }^{(9,16,18)}$, proved to be adequate to the proposed polyamine analysis.

Under the chromatographic extraction conditions of the tissue polyamines used according to the reference description, putrescine was not detected for its concentration being below the detection methods reproduced by us. The measures for sample concentration elevated 5 times the final mass injected into the HPLC and putrescine became detectable and quantifiable in the samples. The different properties of the stationary phase of the columns used in this study (LiChrospher ${ }^{\circledR}$ ) and by Löser et al. (NovaPak ${ }^{\circledR}$, such as particle and pore size, surface area, carbon load, greater silanol groups exposition, with consecutive greater hydrophobicity and polarity, can identify and explain the difference in efficiency for basic compounds between the columns $^{(3)}$. Gennaro et $a l^{(5)}$, in a study about different chromatographic C18 columns adequacy for the ionic interaction transference method in the HPLC, comparing the ruggedness in the transference of methods between five different commercial products, with silica $5 \mu \mathrm{m}$ stationary phases (RP-18), concluded that the critical parameter to be considered in column change between methods is the mobile phase $\mathrm{pH}$, which must be strictly controlled for performance maintenance. With the LiChrospher ${ }^{\otimes}$ column, the minimum $\mathrm{pH}$ deviations up to $\pm 2.5 \%$ in the mobile phase are tolerated ${ }^{(5)}$, which we considered in the present study. Löser et al.(9) reported the usage of a 1:10 final dilution for sample concentration.

The polyamines concentration in tissues can be expressed in nanomoles per tissue gram and the normalization in milligrams of protein shows similar results, also noted by Deignan et al.(4). The spermidine/spermine ratio has been used as a more reliable measure for the spermidine formation during the polyamine inter-conversion cycle $^{(13)}$. Hixson et al. ${ }^{(7)}$ reported that the ratio spermidine/spermine is the less susceptible indicator to measure mistakes because it does not depend on a second measure for normalization, like the weight or protein content of the samples.

\section{Acknowledgements}

The authors express gratefulness to Prof. Dr. Pierina Sueli Bonato, from the Phisics and Chemistry Department of the Farmaceutical Sciences Faculty of Ribeirão Preto (USP), for her valuable orientation on the polyamines chromatographic method validation.

\section{References}

1. BIOANALYTICAL Method Validation, Guidance for Industry, Center for Drug Evaluation and Research (CDER), 2001. Available in: <http://www.fda.gov/cder/ guidance/4252fnl.pdf>.

2. BRADFORD, M. M. A rapid and sensitive method for the quantitation of microgram quantities of protein utilizing the principle of protein-dye binding. Analytical Biochemistry, v. 72, p. 248-54, 1976.

3. COMPARISION guide to $\mathrm{C} 18$ reversed phase HPLC columns. Available in: <http://ACE-PLC.com/assets/downloads/ ACE_Comparision_Guide_2006.pdf $>$.

4. DEIGNAN, J. L. et al. Polyamine homeostasis in arginase knockout mice. Am J Physiol Cell Physiol, v. 293, p. C1296-C1301, 2007.

5. GENNARO, M. C.; ANGELINO, S.; GIANOTTI, V. Suitability of different $\mathrm{C} 18$ silica-based stationary phases for the transferability of an ion-interaction HPLC method. Analysis, v. 27, p. 742-8, 1999.

6. HALLINE, A. G.; DUdEJA, P. K.; BRASITUS, T. A. 1,2-Dimethylhydrazine-induced alterations in N1-acetylspermidine levels and spermidine $\mathrm{N} 1$-acetyltransferase acivity in rat colonic mucosa. Cancer Research, v. 49, p. 633-8, 1989.

7. HIXSON, L. J. et al. Sources of variability in estimating ornithine decarboxylase activity and polyamine contents in human colorectal mucosa. Cancer Epidemiology, Biomarkers \& Prevention, v. 3, p. 317-23, 1994.

8. INTERNATIONAL Conference on Harmonization, Harmonized Tripartite Guideline, Validation of Analytical Procedures, Text and Methodology, Q2(R1). Available in: <http://www.ich.org/LOB/media/MEDIA417.pdf>. Access on: Nov. 2005. 
9. LÖSER, C. et al. Dietary polyamines are essential luminal growth factors for small intestinal and colonic mucosal growth and development. Gut, v. 44, p. 12-6, 1999.

10. LÖSER, C.; WUNDERLICH, U.; FÖLSCH, U. R. Reversed-phase liquid chromatographic separation and simultaneous fluorimetric detection of polyamines and theirs monoacetyl derivatives in human and animal urine, serum and tissue samples: an improved, rapid and sensitive method for routine application. Journal of Chromatography, v. 430, p. 249-62, 1988.

11. PEGG, A. E. Polyamine metabolism and its importance in neoplastic growth and as a target for chemotherapy. Cancer Research, v. 48, p. 759-74, 1988.

12. SEILER, N. Catabolism of polyamines. Amino Acids, v. 26, p. 217-33. 2004.

13. SEILER, N.; BOLKENIUS, F. Polyamine reutilization and turnover in brain. Neurochem Res, v. 10, p. 529-44, 1985.
14. SNYDER, L. R.; KIRKLAND, J. J.; GLAJCH, J. L. Completing the method: validation and transfer in Practical HPLC method development. 2. ed. USA: John Wiley \& Sons, Inc., 1997. p. 687-713.

15. TABOR C. W.; TABOR, H. Polyamines. Annu Rev Biochem, v. 53, p. 749-90, 1984.

16. TIBERIO, L.; MAIER, J. A. M.; SCHIAFFONATI, L. Down-regulation of c-myc expression by phorbol ester protects CEM T leukaemia cells from starvationinduced apoptosis: role of ornithine decarboxylase and polyamines. Cell Death and Differentiation, v. 8, p. 967-76, 2001.

17. WALLACE, H. M. The physiological role of the polyamines. European Journal of Clinical Investigation, v. 30, p. 1-3, 2000.

18. WALTERS, J. D. et al. An inhibitor of polyamine biosynthesis impairs human polymorphonuclear leukocyte priming by tumor necrosis factor alpha. J Leukoc Biol, v. 57, p. 282-6, 1995. 